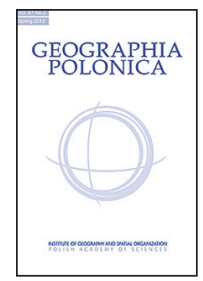

\title{
CHANGES IN UV RADIATION INTENSITY AND THEIR POSSIBLE IMPACT ON SKIN CANCER IN POLAND
}

\author{
Krzysztof Błażejczyk ${ }^{1}$ • Anna Błażejczyk ${ }^{2}$ \\ ${ }^{1}$ Polish Academy of Sciences \\ Institute of Geography and Spatial Organization \\ Twarda 51/55, 00-818 Warszawa: Poland \\ e-mail address: k.blaz@twarda.pan.pl \\ ${ }^{2}$ Bioclimatology \\ Laboratory of Bioclimatology and Environmental Ergonomics \\ Łukowska 17/55, 04-133, Warszawa, Poland
}

\begin{abstract}
UV radiation is a high-energy part of sunlight. Simultaneous changes in global radiation have been observed during recent decades. Close relationships have been found between UV intensity near ground level and the destruction of the stratospheric ozone layer known as the ozone hole. This has great consequences for all ecological systems on Earth as well as for human health. The UV Index (UVI) was developed for the monitoring of the level and composition of UV rays reaching the lower troposphere. The paper presents changes in the UVI in Poland in the period 1996-2011. We also discuss the possible influence of changes in level of ultraviolet radiation (represented by UVI) on the frequency of skin cancer.
\end{abstract}

\section{Key words}

UV radiation $\cdot$ UVI $\cdot$ skin cancer $\cdot$ Poland $\cdot$ climate change

\section{Introduction}

Solar radiation is the main determinant of climate and energy source for living processes on Earth. The input of solar radiation to the ground is regulated both by solar activity and by the physi$\mathrm{cal}$ and chemical features of the atmosphere. The most active range of solar radiation is the ultraviolet, and especially UV-B (Tab.1).

Table 1. Biological effects of various spectral ranges of solar radiation.

\begin{tabular}{|c|c|c|}
\hline Range of solar radiation & Wave length $(\mu \mathrm{m})$ & Biological effects \\
\hline Far ultraviolet (UV-C) & $0.200-0.280$ & germicidal effect, destruction of living cells \\
\hline Middle ultraviolet (UV-B) & $0.281-0.315$ & $\begin{array}{l}\text { erythemal effect, late pigmentation, anti-rickets and germicidal effects, skin } \\
\text { ageing, cataract, skin cancer, reduction of immunity }\end{array}$ \\
\hline Near ultraviolet (UV-A) & $0.316-0.400$ & immediate pigmentation, skin ageing, psoriasis treatment \\
\hline Visible radiation & $0.401-0.760$ & $\begin{array}{l}\text { stimulation of nervous and hormonal systems, regulation of circadian } \\
\text { rhythms }\end{array}$ \\
\hline Infrared & $0.761-4.000$ & thermal effect, stimulation of metabolism \\
\hline
\end{tabular}

Source: Jendritzky (1995). 
UV radiation has several positive features (e.g. in the erythemal effect, late pigmentation, anti-rickets and germicidal effects, anti bacterial effects), which are widely used in medical treatment, especially in heliotherapy in health resorts (Green et al. 1992; Sokołowski et al. 2008). However, large doses of UV can involve several pathological effects in an organism, e.g. skin and eye diseases as well as disturbances to the immune system (Lucas et al. 2006; Confalonieri et al. 2007). The list of radiation related diseases is relatively long, from mild effects like a tendency to excessive drying of the skin, skin discolouration and hardening, skin aging and sunburn up to the destruction of the DNA in skin cells leading to various forms of skin cancer including melanoma. UV radiation can also influence the eye system and can induce cataract. Photo-allergies are also more frequent (Lityńska et al. 2001; Kieć-Świerczyńska \& Kręcisz 2008).

The UV index (UVI) is used to compare the intensity of ultraviolet radiation near ground level (Vanicek et al. 1999). The UVI is an international standard measure of the strength of solar ultraviolet radiation at a particular place. It is a unit for measuring UV levels relevant to its effects on human skin (UV induced erythema). UVI is defined as the effective irradiance obtained by integrating the spectral irradiance weighted by the CIE (International Commission on Illumination) reference action spectrum for UV-induced erythema on the human skin (ISO 1999) up to and including $400 \mathrm{~nm}$ normalised to 1.0 at $297 \mathrm{~nm}$. UVI is expressed numerically as the equivalent of multiplying the time weighted average effective irradiance $\left(\mathrm{W} \cdot \mathrm{m}^{-2}\right)$ by 40 (e.g. an effective irradiation of $0.2 \mathrm{~W} \cdot \mathrm{m}^{-2}$ corresponds to a UV Index of 8.0). The UVI is a dimensionless quantity defined by the following formula (WHO 2002):

$$
U V I=k_{e r} \cdot \int_{250 n m}^{400 n m} E_{\lambda} \cdot s_{e r}(\lambda) d \lambda
$$

where:

$E_{\lambda}$ - is the solar spectral irradiance (expressed in $\mathrm{W} \cdot \mathrm{m}^{-2} \cdot \mathrm{nm}^{-1}$ ) at wavelength $\lambda$,

$d \lambda$ - is the wavelength interval used in the summation, $s_{e r} \lambda$ - is the erythema reference action spectrum,

$k_{e r}-$ is a constant equal to $40 \mathrm{~m}^{2} \cdot \mathrm{W}^{-1}$.

UVI is categorized according to possible health risks. Several recommendations regarding protection against UV risks are given in Table 2. One of the most important health risks is skin cancer.

The aim of the paper is to present seasonal as well as multiannual changes in UVI in Poland. We will also discuss the possible influence of UV radiation (expressed by UVI) on skin cancer morbidity in Poland.

\section{Materials and methods}

The basic data concerning UV index were taken from the UV Radiation Monitoring Service of the Tropospheric Emission Monitoring Internet Service (TEMIS, http://www.temis.nl/uvradiation) affiliated to the Dutch Meteorological Service. The service provides UVI values which are derived from total ozone column data as measured by GOME (the Global Ozone Monitoring Experiment, http://www. temis.nl/uvradiation/GOME), on board the ERS-2

Table 2. UVI Assessment scale.

\begin{tabular}{|c|l|l|}
\hline UVI & \multicolumn{1}{|c|}{ Health risks } & \multicolumn{1}{c|}{ Possible protection } \\
\hline $0-2$ & $\begin{array}{l}\text { No danger to the average person } \\
\text { Little risk of harm from unprotected } \\
\text { exposure to the sun } \\
\text { High risk of harm from unprotected } \\
\text { exposure to the sun }\end{array}$ & $\begin{array}{l}\text { No action necessary. } \\
\text { Wear sunglasses and use SPF 30+ sunscreen, cover the body with clothing } \\
\text { and a hat, and seek shade around midday when the sun is most intense. } \\
\text { Wear sunglasses and use SPF 30+ sunscreen, cover the body with sun } \\
\text { protective clothing, wear a wide-brim hat, and reduce time in the sun from } \\
\text { two hours before to three hours after solar noon (roughly 11:00 to 16:00 } \\
\text { during summer). } \\
\text { Wear SPF 30+ sunscreen, a shirt, sunglasses, and a hat. Do not stay out in } \\
\text { the sun for too long. } \\
\text { Take all precautions, including: wear sunglasses and use SPF 30+ sunscreen, } \\
\text { cover the body with a long-sleeve shirt and trousers, wear a very broad hat, } \\
\text { and avoid the sun from two hours before to three hours after solar noon } \\
\text { (roughly 11:00 to 16:00 during summer). }\end{array}$ \\
\hline
\end{tabular}

Source: WHO (2002); EPA (2011). 
(European Remote Sensing) satellite and SCIAMA$\mathrm{CHY}$ (the SCanning Imaging Absorption spectroMeter for Atmospheric CartograpHY, http://www. temis.nl/uvradiation/SCIA) on board the European Space Agency satellite ENVISAT (ENVIronmental SATellite) (van Geffen et al. 2004). The daily data for 4 Polish stations: Łeba, Legionowo, Belsk and Zakopane, for the period August 1995 - March 2012 are available there. The data represent UVI calculated for clear sky conditions. The TEMIS service also provides hourly data on the total ozone column for the period November 1978 - December 2008. The data from Kaunas, Potsdam and Poprad were taken to characterise the situation on Polish territory. Additionally the data for the North Pole and Vostok stations were analysed for comparison. The TEMIS ozone column dataset was supplemented by observations carried out at the Geophysical Observatory in Belsk for the period 1963-2008 reported by Chief Inspectorate of Environmental Protection (GIOŚ 2009).

Skin cancer data for Poland are available in special reports of the Centre of Oncology for the period 1999-2009 (Ministry of Health 2010). The register provides information about the total number and standardised value (per 100,000 inhabitants) of melanoma and other skin cancers. Data regarding skin melanoma deaths in the period 1961-2009 were adapted from the website of the World Health Organization's International Agency for Research on Cancer (WHO 2012).

In the paper seasonal fluctuations of UVI, calculated as average values of the four Polish stations used for consecutive days of the year for the period 1996-2011, are discussed. The changes in UVI are compared with fluctuations in total ozone column in the atmosphere. The statistical analyses were made using the STATGRAPHICS 2.0 software package.

\section{Results}

\section{UVI variations}

The data from Belsk Geophysical Observatory show that UVI values are closely correlated with total ozone column in the atmosphere. UVI increases proportionately to the decrease in ozone column (Fig. 1). Both, mean and maximum annual values of UV index are significantly correlated (at the $99 \%$ confidence level) with ozone content.

The UV index is a function of the intensity of ultraviolet radiation. We must remember that UV intensity is not only influenced by total ozone column, but also by cloud cover, atmospheric aerosols, sun elevation and altitude. Thus, a clear annual cycle of UVI is observed with the lowest values (below 1.0) being registered in the winter months. Winter is the period when UVI shows very little regional variation. Summer peaks of mean index values vary from about 6 in Łeba through 6.5 in central Poland (Belsk, Legionowo) up to 7.5 in Zakopane. This is an effect of the altitude of the sun (smallest in the north - Łeba and highest in the south - Zakopane) and elevation above sea level; while Łeba is a coastal station, Zakopane is located at about 1,000 m a.s.l. It can be a little confusing that there are high UVI values in Zakopane

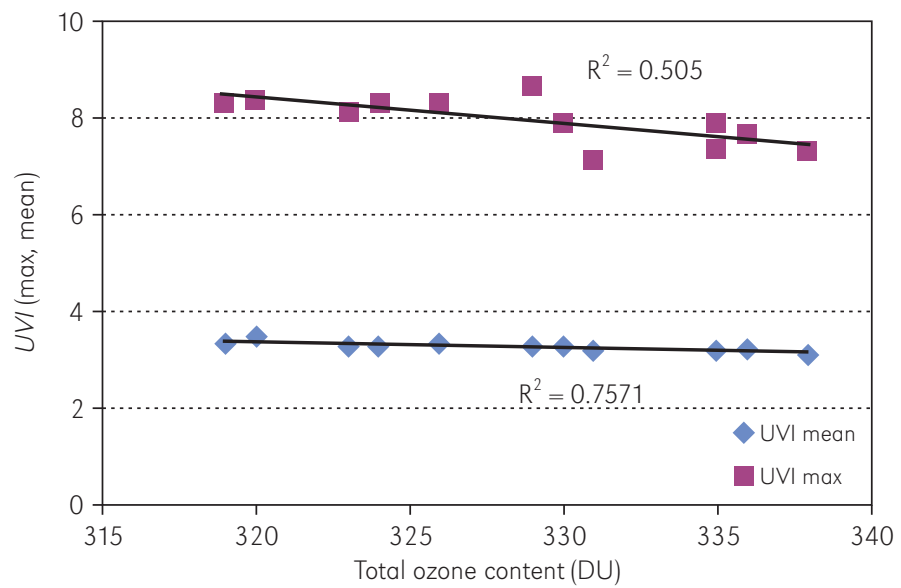

Figure 1. Relationships between total ozone content in the atmosphere and mean annual (UVI mean) and maximum annual (UVI max) values of UV index in Belsk, 1996-2008. 
which is a mountain town characterised by increased air pollution and cloudiness. However, the UVI values used in the paper represent clear sky conditions and do not take into consideration local features of the locations being compared (Fig. 2).

UVI changed significantly during observation period (1996-2011) at all Polish stations examined. Mean annual values of the index increased gradually (Fig. 3). The trends lines are significant at 90 and $95 \%$ confidence levels. Significant trends (at 95 and 99\% levels) are also observed for the frequency of days with UVI > 6 (these values of UVI indicate at least a high risk of harm from unprotected exposure to the sun). The increase is observed in central and northern Poland while in Zakopane (mountain region) the number of days with high UVI risk is relatively stable and the trend line for this characteristic is insignificant (Tab. 3).

Table 3. Correlation coefficients of trend lines of UVI avg and days with UVI > 6, 1996-2011.

\begin{tabular}{|l|c|c|}
\hline \multicolumn{1}{|c|}{ Station } & UVI avg & Days with UVI > 6 \\
\hline Łeba & $0.484^{\star}$ & $0.500^{\star \star}$ \\
Belsk & $0.486^{\star}$ & $0.715^{\star \star \star}$ \\
Legionowo & $0.456^{\star}$ & $0.646^{\star \star \star}$ \\
Zakopane & $0.507^{\star \star}$ & - \\
\hline
\end{tabular}

Statistical significance of trend lines at confidence levels: ${ }^{\star}-90 \%,{ }^{\star \star}-95 \%,{ }^{\star \star \star}-99 \%$.

In Zakopane, which is the region with the highest mean UVI values, the frequency of dangerous
UV conditions is two times higher than in central Poland and even 5 times higher than on the Baltic coast (Łeba) (Fig. 3). The increased frequency of days with high UVI values in Zakopane can be explained by the high altitude of this station (about 1,000 $\mathrm{m}$ a.s.l.); in general, intensity of solar radiation rises with increase in altitude (Błażejczyk 1998; Bogdańska \& Podogrocki 2000).

\section{Ultraviolet radiation and skin cancer}

During the last 50 years a significant increase in skin melanoma deaths has been observed in Poland. While less then 100 people died annually from skin melanoma in the early 1960s, in the first decade of 21 st century the number of fatalities had reached 1,100-1,200 (Fig. 4). The reduction in the ozone column over Poland, especially during the last 40 years, can be considered as one 


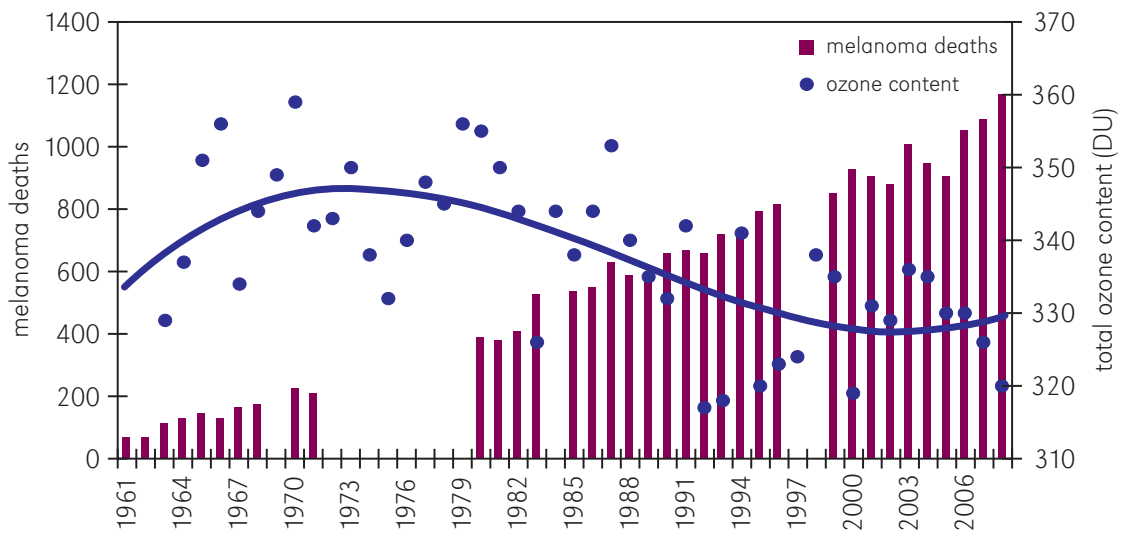

Figure 4. Changes in melanoma deaths in Poland and total ozone content over Poland (Geophysical observatory in Belsk) (the blue line presents a polynomial function of ozone content).

Source: Rajewska-Więch (2009); WHO (2012).

of the factors which influence the dramatic rise in incidence of skin melanoma and deaths. As shown in Figure 1, the reduction in ozone content in the atmosphere has resulted in an increase in UV index. An additional cause of the increased number of skin cancer cases is a change in people's behaviour (use of solaria, sunbathing, spending winter holidays in tropical and subtropical countries etc.).

The reduction in stratospheric ozone is mainly observed over the southern hemisphere (from about $280 \mathrm{DU}$ in 1980 to about 240-250 DU at the beginning of 21st century). The content of stratospheric ozone over the northern hemisphere is significantly higher than over Antarctica. However, both at the North Pole and in central Europe, the ozone content was reduced from about $350 \mathrm{DU}$ in 1980 to about 320 DU in 2008 (Tab. 4).

Detailed analysis of newly registered cases of skin cancer in Poland is possible for the period 1999-2009. During this period the total number of skin cancers gradually rose from about
Table 4. Ozone content (DU) in the atmosphere at selected stations in central Europe as well as over the North Pole and in Antarctica (Vostok station).

\begin{tabular}{|c|c|c|c|c|c|c|}
\hline Year & Potsdam & Poprad & Kaunas & North Pole & Vostok & Belsk \\
\hline 1979 & 351 & 347 & 352 & 357 & 287 & 356 \\
\hline 1980 & 350 & 348 & 355 & 349 & 289 & 355 \\
\hline 1981 & 346 & 348 & 350 & 336 & 287 & 350 \\
\hline 1982 & 345 & 345 & 346 & 333 & 276 & 344 \\
\hline 1983 & 324 & 326 & 324 & 329 & 266 & 326 \\
\hline 1984 & 344 & 342 & 343 & 344 & 267 & 344 \\
\hline 1985 & 339 & 334 & 343 & 347 & 249 & 338 \\
\hline 1986 & 340 & 338 & 339 & 326 & 260 & 344 \\
\hline 1987 & 343 & 341 & 348 & 366 & 252 & 353 \\
\hline 1988 & 334 & 336 & 340 & 339 & 280 & 340 \\
\hline 1989 & 332 & 332 & 334 & 340 & 262 & 335 \\
\hline 1990 & 328 & 329 & 329 & 310 & 250 & 332 \\
\hline 1991 & 338 & 341 & 339 & 345 & 259 & 342 \\
\hline 1992 & 314 & 315 & 315 & 329 & 244 & 317 \\
\hline 1993 & 314 & 314 & 313 & 323 & 256 & 318 \\
\hline 1994 & 334 & 334 & 336 & 341 & 266 & 341 \\
\hline 1995 & 319 & 321 & 319 & 322 & 253 & 320 \\
\hline 1996 & 321 & 325 & 319 & 331 & 246 & 323 \\
\hline 1997 & 318 & 322 & 323 & 314 & 248 & 324 \\
\hline 1998 & 335 & 336 & 339 & 353 & 244 & 338 \\
\hline 1999 & 334 & 332 & 335 & 349 & 240 & 335 \\
\hline 2000 & 323 & 323 & 324 & 324 & 253 & 319 \\
\hline 2001 & 334 & 332 & 337 & 358 & 241 & 331 \\
\hline 2002 & 325 & 326 & 327 & 335 & 278 & 329 \\
\hline 2003 & 331 & 335 & 334 & 345 & 247 & 336 \\
\hline 2004 & 332 & 332 & 335 & 345 & 264 & 335 \\
\hline 2005 & 326 & 330 & 327 & 326 & 252 & 330 \\
\hline 2006 & 330 & 329 & 332 & 355 & 246 & 330 \\
\hline 2007 & 328 & 329 & 328 & 329 & 239 & 326 \\
\hline 2008 & 323 & 322 & 324 & 335 & 251 & 320 \\
\hline
\end{tabular}

Source: GIOŚ (2009); ozone data from TM3DAM-MSR1 (http://www.temis.nl/protocols/o3field/overpass_msr1.html). 
Table 5. Number of the cases of skin melanoma and other skin cancers registered in Poland in the years 1999-2009.

\begin{tabular}{|l|c|c|c|c|c|c|c|c|c|c|c|}
\hline \multicolumn{1}{|c|}{ Type of cancer } & 1999 & 2000 & 2001 & 2002 & 2003 & 2004 & 2005 & 2006 & 2007 & 2008 & 2009 \\
\hline Skin melanoma & 1,606 & 1,731 & 1,757 & 1,831 & 1,985 & 1,926 & 2,188 & 2,101 & 2,195 & 2,286 & 2,562 \\
Other skin cancers & 5,302 & 5,362 & 5,672 & 6,124 & 6,818 & 6,945 & 8,310 & 8,230 & 8,307 & 8,679 & 9,291 \\
\hline
\end{tabular}

Source: Ministry of Health (2010).

7,000 in 1999 to almost 12,000 in 2009. The rate of the most dangerous skin melanoma was relatively stable and during whole period analysed it consisted of about $20-24 \%$ of all cases of skin cancer (Tab. 5).

The incidence of skin cancer cases per 100,000 population changed from 25 in 1999 to over 35 in 2009 (a 40\% increase). In general, the male population is more affected by skin cancers than the female population. The relationship is 55\% to $45 \%$ (Fig. 5).

The observation series of UVI and skin cancers are relatively short. However, the resource of
11 years of detailed registers of cancer deaths allows some findings to be defined. For the analysis, the absolute number of all skin cancers and skin melanomas was compared with various characteristics of UV radiation, averaged for UVI data from all the observation stations in Poland (Łeba, Legionowo, Belsk and Zakopane).

Figure 6 shows the statistical relationships between skin cancer cases (both, all and melanoma) and mean UVI values in Poland. The correlation coefficients between the values being compared are significant at the $95 \%$ confidence level for all

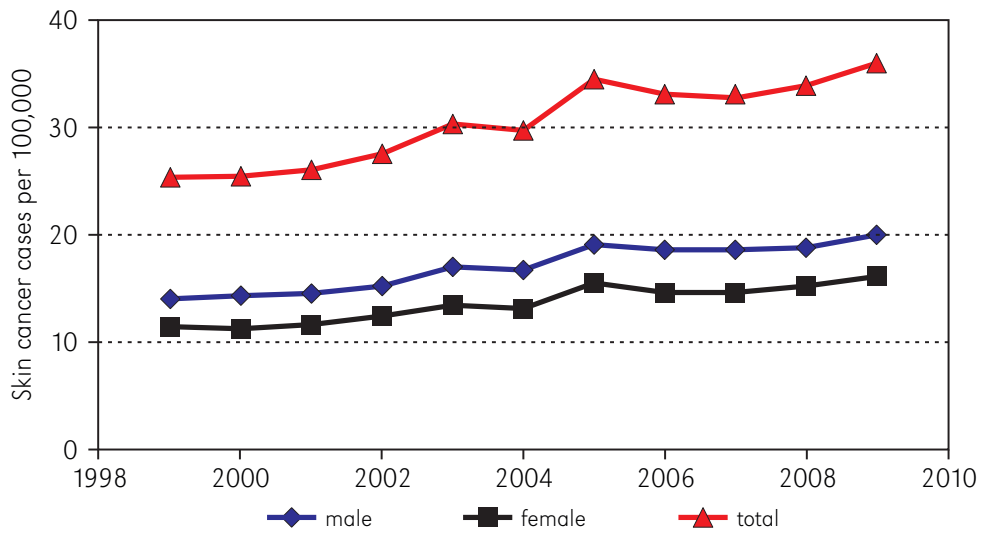

Figure 5. Rates of all skin cancer cases per 100,000 population in Poland.

Source: Ministry of Health (2010).
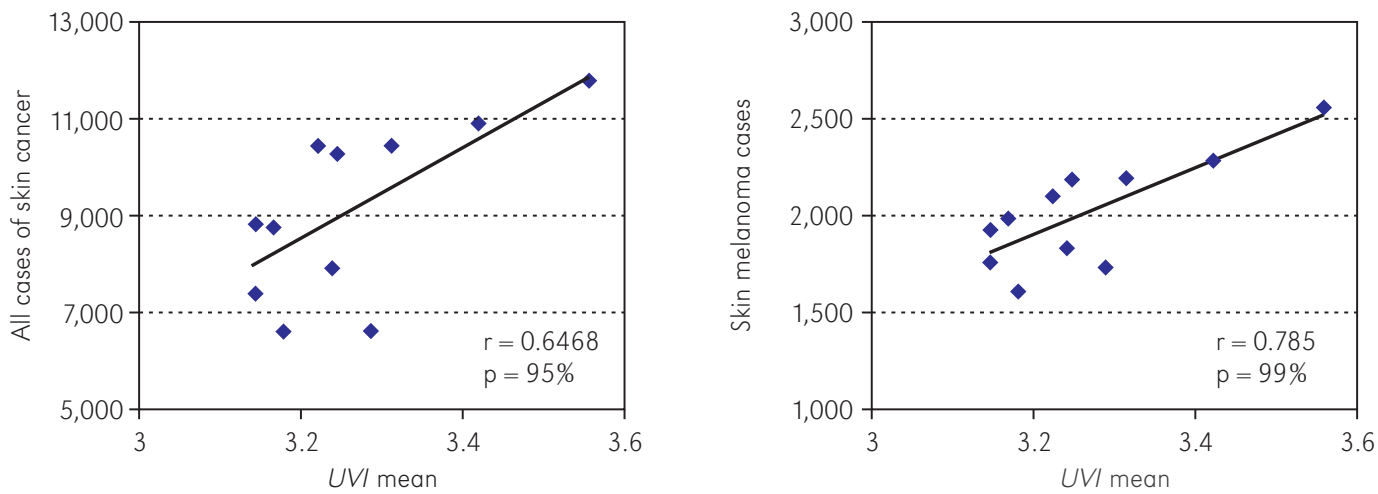

Figure 6. Relationships between mean annual values of UV index for Poland (UVI mean) and all cases of skin cancer as well as skin melanoma, 1999-2009. 


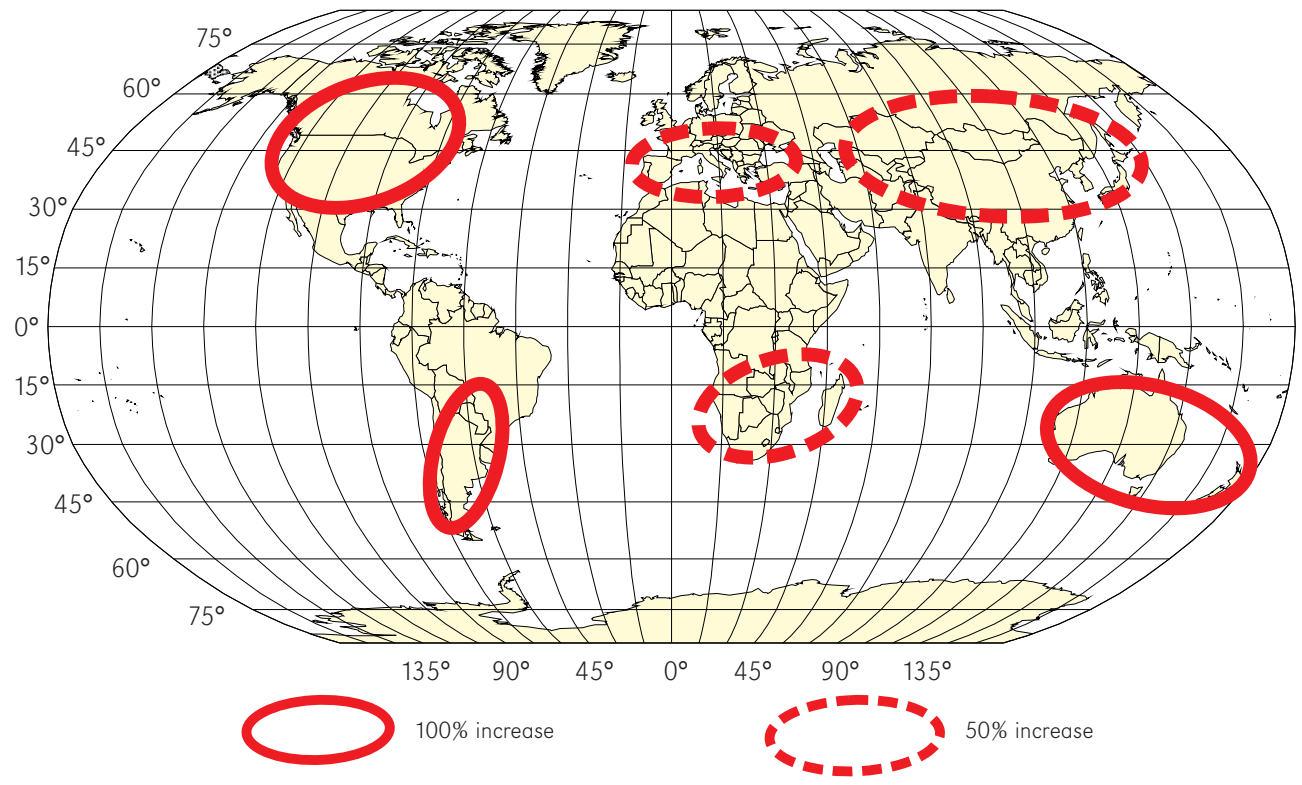

Figure 7. Increase in skin cancer in the period 2020-2060: 1 - 50\% increase, 2 - 100\% increase.

Source: Bovet et al. (2007).

cases of skin cancer and at the $99 \%$ level for skin melanoma. More than $40 \%$ of skin cancers in particular years can be explained by the changes in mean annual value of the UV index. For skin melanoma, the correlation coefficient is even higher and about $62 \%$ of this disease can be explained by UVI value. For other UVI characteristics (UVI max, days with $U V I>6$ ) the relationships are statistically insignificant.

\section{Conclusions}

The change in UV radiation reaching the lower troposphere is an effect of the reduction in the stratospheric ozone layer, a phenomenon which has been observed in both the southern and northern hemispheres. The degradation of stratospheric ozone leads to an increase in skin cancer. The forecasts for the next 50 years are very worrying. Simulations made in the Dutch Institute of Public Health indicate a $50 \%$ increase in skin cancer in the Mediterranean countries and central Europe (including Poland), in the centre of Asia and in southern Africa and a $100 \%$ rise in Argentina, United States and Australia (Fig. 7). To reduce such a risk the WHO propose intensifying educational efforts presenting the sun as an important factor in health problems (WHO 2003). The recommendations should also be applied to Poland ( $\mathrm{WHO} /$ ICO 2010).

Changes in UVI, especially its mean annual values and the frequency of days with UVI > 6 (or at least, a high risk of harm from unprotected exposure to the sun) have been observed in the first decade of 21st century. The changes in UV index lead to significant increases in skin melanoma and other skin cancers.

\section{Editors' note:}

Unless otherwise stated, the sources of tables and figures are the author(s), on the basis of their own research. 


\section{References}

BŁAŻEJCZYK K., 1998. Promieniowanie słoneczne a gospodarka cieplna organizmu człowieka. Zeszyty IGiPZ PAN, no. 51, Warszawa: Instytut Geografii i Przestrzennego Zagospodarowania PAN, 85 pp.

Bogdańska B., Podogrocki J., 2000. Zmienność catkowitego promieniowania słonecznego na obszarze Polski w okresie 1961-1995. Materiały Badawcze, ser. Meteorologia, vol. 30, Warszawa: Instytut Meteorologii i Gospodarki Wodnej, 43 pp.

Bovet P., Rekacewicz P., Sinaï A., Vidal D., 2007. L'Atlas environnement. Analyses et solutions, Paris: Le Monde diplomatique, $100 \mathrm{pp}$.

Confalonieri U., Menne B., Akhtar R., Ebi K.L., Hauengue M., Kovats R.S., Revich B., Woodward V., 2007. Human Health [in:] M.L. Parry, O.F. Canziani, J.P. Palutikof, P.J. van der Linden, C.E. Hanson (eds.), Climate Change 2007: Impacts, Adaptation and Vulnerability. Contribution of Working Group II to the Fourth Assessment Report of the Intergovernmental Panel on Climate Change, Cambridge: Cambridge University Press, pp. 391-431.

EPA, 2011. UV Index Scale. Environmental Protection Agency, http://www.epa.gov/sunwise/uviscale.html [23 January 2013].

GIOŚ, 2009. Badania stanu warstwy ozonowej nad Polska oraz pomiary natężenia promieniowania UV. Warszawa: Główny Inspektorat Ochrony Środowiska, http://www.gios.gov.pl/artykuly/128/Badaniastanu-warstwy-ozonowej-nad-Polska-oraz-pomiarynatezenia-promieniowania-UV [23 January 2013].

Green C., Diffey B.L., HaWk J.L.M., 1992. Ultraviolet radiation in the treatment of skin disease. Physics in Medicine and Biology, vol. 37, no. 1, pp. 1-20.

ISO, 1999. Erythema reference action spectrum and standard erythema dose. ISO 17166:1999 (CIE S 007/E:1998).

JeNDRITZKY G., 1995. Human health and atmospheric environment [in:] Report from the Meeting of Experts on Climate, Tourism and Human Health. Topes de Collantes, Cuba, 22-29 January 1995. WCASP 33, WMO/TD, no. 682, Geneva: World Meteorological Organization, 44-54 pp.

KieĆ-Świerczyńska M., Kręcisz B., 2008. Fotoalergia [in:] C. Pałczyński, M. Kieć-Świerczyńska, J. Walusiak (eds.), Alergologia zawodowa, Łodź: Instytut Medycyny Pracy, pp. 151-161.
LITYŃSKA Z., ŁAPETA B., WolSKA H., 2001. Indeks UV a człowiek. Przewodnik przeznaczony do praktycznego stosowania i interpretacji słonecznego indeksu UV opracowany przez czwarta Grupę Robocza Akcji COST-713 "Prognoza UV-B". Warszawa: Instytut Meteorologii i Gospodarki Wodnej, 32 pp.

Lucas R., McMichael T., Smith W., Armstrong B., 2006. Solar ultraviolet radiation. Global burden of disease from solar ultraviolet radiation. Environmental Burden of Disease Series, no. 13, Geneva: World Health Organization, $250 \mathrm{pp}$

Ministry of Health, 2010. National Cancer Registry, http://epid.coi.waw.pl/krn [23 January 2013].

RAJEWSKA-WIĘCH B., 2009. Stan warstwy ozonowej. Warszawa: Instytut Geofizyki PAN, http://www.gios. gov.pl//zalaczniki/artykuly/stan\%20warstwy\%20 ozonowej-brw.pdf [23 January 2013].

SOKOŁOWSKI K., Staniak D., Latosiewicz R., 2008. Korzystny wpływ promieniowania ultrafioletowego na człowieka. Balneologia Polska, vol. 50, no. 4, pp. 294-300.

van Geffen J., van der A R., van Weele M., Allaart M., ESKES H., 2004. Surface UV radiation monitoring based on GOME and SCIAMACHY [in:] Proceedings of the ENVISAT \& ERS Symposium, 6-10 September 2004, Salzburg, Austria, ESA publication SP-572, $10 \mathrm{pp}$.

Vanicek K., Frei T., Litynska Z., Schmalwieser A., 1999. UV-Index for the Public. A guide for publication and interpretation of solar UV Index forecasts for the public prepared by the Working Group 4 of the COST-713 Action "UVB Forecasting". Brussels: COST713 Action, 28 pp.

WHO, 2002. Global Solar UV Index: A Practical Guide. Geneva: World Health Organization, 28 pp.

$\mathrm{WHO}, 2003$. Strategies to improve and strengthen cancer control programmes in Europe. Report of a WHO Consultation, Geneva, 25-28 November, 2003. Geneva: World Health Organization, 30 pp.

$\mathrm{WHO} / \mathrm{ICO}, 2010$. Human Papillomavirus and Related Cancers in Poland. Summary Report 2010. Barcelona: World Health Organization, Institut Català d'Oncologia (HPV Information Centre), http://apps. who.int/hpvcentre/statistics/dynamic/ico/SummaryReportsSelect.cfm [23 January 2013].

WHO, 2012. Cancer Mortality Database. Lyon: World Health Organization, International Agency for Research on Cancer, http://www-dep.iarc.fr/WHOdb/ WHOdb.htm [23 January 2013].
(C) Krzysztof Błażejczyk, Anna Błażejczyk

(C) Geographia Polonica

(C) Institute of Geography and Spatial Organization,

Polish Academy of Sciences, Warsaw, 2012
Article first received • January 2012 Article accepted • June 2012 